\title{
Quantitative profiling and dynamics of mRNA modifications in Escherichia coli
}

\author{
Dimitar Plamenov Petrov ${ }^{1}$, Steffen Kaiser ${ }^{2,3}$, Stefanie Kaiser ${ }^{2,3^{*}}$ and Kirsten Jung ${ }^{1 *}$ \\ ${ }^{1}$ Department of Biology I, Microbiology, Ludwig-Maximilians-University Munich, Martinsried, Germany. \\ 2 Department of Chemistry, Ludwig-Maximilians-University Munich, Munich, Germany. ${ }^{3}$ Department of \\ Pharmacy, Goethe-University Frankfurt, Frankfurt, Germany. \\ * To whom correspondence should be addressed. Email: jung@lmu.de; kellner@pharmchem.uni- \\ frankfurt.de
}

\begin{abstract}
mRNA methylation is an important regulator of many physiological processes in eukaryotes but has not been studied in depth in prokaryotes. In contrast to the large number of eukaryotic mRNA modifications that have been described, $N^{6}$-methyladenosine $\left(m^{6} A\right)$ is the only modification of bacterial mRNA identified to date. Here, we used a gel electrophoresis-based RNA separation method and quantitatively analyzed the mRNA-specific modification profile of Escherichia coli using mass spectrometry. In addition to $\mathrm{m}^{6} \mathrm{~A}$, we provide evidence for the presence of 7-methylguanosine $\left(\mathrm{m}^{7} \mathrm{G}\right)$, and we found first hints for 5-methylcytidine $\left(\mathrm{m}^{5} \mathrm{C}\right), N^{6}, N^{6}$-dimethyladenosine $\left(\mathrm{m}^{6,6} \mathrm{~A}\right)$, 1-methylguanosine $\left(\mathrm{m}^{1} \mathrm{G}\right)$, 5methyluridine $\left(\mathrm{m}^{5} \mathrm{U}\right)$, and pseudouridine $(\Psi)$ in the mRNA of $E$. coli, which implies that $E$. coli has a complex mRNA modification pattern. Furthermore, we observed changes in the abundance of some mRNA modifications during the transition of $E$. coli from the exponential growth to the stationary phase as well as upon exposure to stress. This study reveals a previously underestimated level of regulation between transcription and translation in bacteria.
\end{abstract}

\section{INTRODUCTION}

Chemical modification of DNA is a well-known epigenetic regulatory mechanism. The recent development of highly sensitive analytical techniques has discovered increasing numbers of RNA modifications leading to new aspects of RNA regulation in the emerging field of epitranscriptomics. To date, more than 160 RNA modifications have been described in all domains of life ${ }^{1,2}$. Eukaryotes carry both reversible and irreversible RNA modifications in their messenger RNA (mRNA). These mRNA modifications play an important role in RNA editing, splicing, and 5'-capping, and some also have regulatory effects on RNA stability and translational fidelity (reviewed $\mathrm{in}^{3,4}$ ].

In eukaryotes, tRNA and rRNA modifications can affect the whole protein synthesis in the cell, whereas several mRNA modifications have been shown to be posttranscriptional regulators of specific gene expression programs involved in cell development and homeostasis ${ }^{5,6}$. Complex machineries, including modification-specific methyltransferases, demethylases, and binding proteins, recognize or change the methylation state of specific mRNAs and consequently affect their fates and functions ${ }^{7}$. $N^{6}$. methyladenosine $\left(\mathrm{m}^{6} \mathrm{~A}\right)$ is the most abundant mRNA modification in eukaryotes and is the best studied example of how mRNA methylation regulates both mRNA stability and gene expression (reviewed $\mathrm{in}^{8}$ ). Pseudouridine
$(\Psi)$, one of the most abundant modifications found in all types of RNA, is also present in the coding sequence of mRNAs and has been reported to affect translational speed and tRNA selection by ribosomes ${ }^{9}$.

Although bacteria have been used as model organisms to study modifications and modifying enzymes of tRNA and rRNA 10,11, knowledge regarding the mRNA modification profile of prokaryotes is extremely limited. Working with bacterial mRNA is challenging because it lacks a poly(A)-tail, which can be used for its enrichment in experimental methods, and its average half-life time is very short (in the range of minutes $)^{12}$. Despite these challenges, in 2015, high-resolution transcriptome-wide $\mathrm{m}^{6} \mathrm{~A}$ profiling for the two bacterial model organisms Escherichia coli and Pseudomonas aeruginosa revealed both conserved and distinct distribution patterns of this modification ${ }^{13}$. The $\mathrm{m}^{6} \mathrm{~A} / \mathrm{A}$ ratios observed $(>0.2 \%)$ were comparable to those of mammals $(0.1 \%-0.4 \%)$ and meiotic yeast $(0.25 \%)$. Most $\mathrm{m}^{6} \mathrm{~A}$-modified transcripts were associated with respiration, amino acid metabolism, stress response, and small RNAs, suggesting a potential regulatory role for mRNA methylation in bacteria. Therefore, it was suggested that RNA methylation might be involved in the adaptation of bacteria to different conditions and developmental stages, as has been demonstrated for eukaryotic cells ${ }^{13}$. Unlike E. coli and Pseudomonas spp., two other Gramnegative cyanobacteria (Anabaena sp. PCC 
7120 and Synechocystis sp. PCC 6803) and representative species of Gram-positive bacteria (Staphylococcus aureus and Bacillus subtilis) showed low $\mathrm{m}^{6} \mathrm{~A} / \mathrm{A}$ ratios $(<0.04 \% \text { and }<0.08 \% \text {, respectively })^{13}$. Finally, 5 -methylcytidine $\left(\mathrm{m}^{5} \mathrm{C}\right)$ has been mapped in the mRNA of the archaeon Sulfolobus solfataricus ${ }^{14}$.

Because $m^{6} A$ is the only described mRNA modification in bacteria, we were interested whether other modifications found in eukaryotes are also present in bacterial mRNA. To address this question, we used a gel electrophoresis-based method to separate RNA from $E$. coli and analyzed the individual fractions by isotope dilution nucleoside mass spectrometry (LC-MS/MS). Our results provide evidence for the presence of not only $\mathrm{m}^{6} \mathrm{~A}$ but also 7-methylguanosine $\left(m^{7} G\right)$, and first hints for 5-methylcytidine $\quad\left(\mathrm{m}^{5} \mathrm{C}\right), \quad N^{6}, N^{6}$ dimethyladenosine $\left(\mathrm{m}^{6,6} \mathrm{~A}\right), 1$-methylguanosine $\left(\mathrm{m}^{1} \mathrm{G}\right), \quad 5$-methyluridine $\left(\mathrm{m}^{5} \mathrm{U}\right), \quad$ and pseudouridine $(\Psi)$ in $E$. coli mRNA. The abundance of some of these modifications is altered during the transition of cells from the exponential growth to the stationary phase. Furthermore, stress conditions like oxygen limitation or acid stress led to changes in the abundance of some mRNA modifications. This study sheds light on a thus far neglected layer of regulation between transcription and translation in bacteria.

\section{RESULTS}

\section{Profiling of RNA modifications in E. coli MG1655}

To investigate the complexity of mRNA modification in bacteria, we used the model organism E. coli MG1655. Since RNA sequencing is only possible for a limited number of modifications ${ }^{15}$, and negative controls are lacking because the modification machinery in bacteria is unknown, we used an LC-MS/MS-based approach. As a starting point, we performed qualitative profiling and comparison of the modifications in the three main RNA types: mRNA (including long noncoding RNA), rRNA (23S and 16S rRNA), and tRNA (including small RNAs less than 110 nucleotides (nt) in length). For this purpose, $E$. coli cells were grown in LB medium and harvested in the early exponential growth phase. Total RNA was isolated using phenolchloroform-isoamyl alcohol (PCI) extraction and separated into tRNA and large RNAs containing both rRNA and mRNA (rRNA+mRNA fraction) by an established size exclusion chromatography (SEC) method ${ }^{16}$. The successful removal of tRNA from the
rRNA+mRNA fraction was verified by chip gel electrophoresis. We observed a clean distinction between the tRNA and rRNA+mRNA fractions (Figure S1A). As an additional control for the efficiency of tRNA separation, we measured $m^{6} A$ levels in the tRNA and rRNA+mRNA fractions in the E. coli wild-type and the mutant $\Delta t r m M$, which lacks the only known methyltransferase for $\mathrm{m}^{6} \mathrm{~A}$ methylation of $\operatorname{tRNA}^{17}$. Whereas the $\mathrm{m}^{6} \mathrm{~A}$ abundance in the rRNA+mRNA fraction remained similar in both strains, only substoichiometric amounts of $m^{6} A$ were detectable after LC-MS/MS analysis in the tRNA fraction of the mutant in contrast to a high level in the wild type, which shows efficient separation between the tRNA and rRNA+mRNA fractions (Figs. S1B-C). Next, the purified $r R N A+m R N A$ fraction was separated into rRNA and mRNA using a commercially available kit for the oligonucleotide-based removal of rRNA. The efficiency of separation was verified by RT-qPCR, and for each mRNA sample, we observed at least a 500-fold decrease in the rRNA amount compared to samples taken before oligonucleotide-based rRNA depletion (Figure S2). Finally, each RNA fraction was enzymatically hydrolyzed, and the resulting nucleoside mixtures were subjected to LC-MS/MS for qualitative analysis of 54 RNA modifications (Figure 1).

For each of the three studied RNA typestRNA, rRNA, and mRNA-we observed a complex profile of modifications, as summarized in Figure 1. As expected, we found the highest chemical diversity in the tRNA fraction, with 26 different modified nucleosides detected. We confirmed numerous known tRNA modifications, and in addition, we detected $N^{1}$ methyladenosine $\left(m^{1} A\right), \quad m^{6,6} A, \quad 2^{\prime}-O-$ methyladenosine (Am), and $\mathrm{m}^{5} \mathrm{C}$ in $E$. coli tRNA. A lower chemical diversity was observed in the mRNA fraction. Here, we detected 15 nucleosides overlapping with either tRNA or rRNA. Along with the only known modification $\mathrm{m}^{6} \mathrm{~A}$, in the mRNA of $E$. coli MG1655, we identified the presence of $m^{1} A, m^{2} A, m^{6,6} A, A m$, $m^{5} \mathrm{C}, 2^{\prime}$-O-methylcytidine $(\mathrm{Cm}), \mathrm{m}^{1} \mathrm{G}, \mathrm{m}^{2} \mathrm{G}, \mathrm{m}^{7} \mathrm{G}$, 2'-O-methylguanosine $(\mathrm{Gm}), \mathrm{m}^{5} \mathrm{U}$, inosine (I), and $\Psi$. In addition, we detected a modified cytidine derivative that is modified at both the ribose and the nucleobase $\left(\mathrm{m}^{\times} \mathrm{Cm}\right)$. According to the literature, this modification is most likely $\mathrm{N} 4,2^{\prime}$-O-dimethylcytidine $\left(\mathrm{m}^{4} \mathrm{Cm}\right)$, but comparison with synthetic standards of $\mathrm{m}^{4} \mathrm{Cm}$ and $\mathrm{m}^{5} \mathrm{Cm}$ revealed co-elution in our system, and so the existence of $\mathrm{m}^{5} \mathrm{Cm}$ cannot be excluded. In the SEC-purified rRNA fraction ${ }^{16}$, we detected 16 modified nucleosides. Three of these modifications, namely, $N^{6}, \quad 2^{\prime}-\mathrm{O}-$ dimethyladenosine $\left(\mathrm{m}^{6} \mathrm{Am}\right), 5$-formylcytidine 
$\left(f^{5} \mathrm{C}\right)$, and inosine, have not been observed previously in the rRNA of $E$. coli ${ }^{10}$. Taken together, the modifications $m^{2} A, m^{6} A, m^{6,6} A$, $\mathrm{m}^{5} \mathrm{C}, \mathrm{m}^{\mathrm{x}} \mathrm{Cm}, \mathrm{Cm}, \mathrm{m}^{1} \mathrm{G}, \mathrm{m}^{7} \mathrm{G}, \mathrm{Gm}, \mathrm{m}^{5} \mathrm{U}, \mathrm{I}$, and $\Psi$ were detected in all three types of RNA in E. coli MG1655 (Figure 1). Furthermore, $\mathrm{m}^{2} \mathrm{G}$ was detectable in the rRNA and mRNA, but not in the tRNA fraction, whereas $\mathrm{m}^{1} \mathrm{~A}$ and Am were found in the tRNA and mRNA fractions but not in the rRNA. The modifications $m^{6} A m$ and $m^{3} \mathrm{U}$ were detected exclusively within the rRNA fraction. However, owing to their low abundance, they cannot be used as internal controls for rRNA contamination. $N^{6}$ threonylcarbamoyladenosine $\quad\left(t^{6} A\right), \quad 2-$ thiocytidine $\left(s^{2} C\right)$, 4-thiouridine $\left(s^{4} U\right)$, and dihydrouridine (D) were found only in the tRNA fraction and might be suitable indicators for contamination with tRNA. Under our test conditions, 25 modifications known from both prokaryotes and eukaryotes were below the limit of detection in our RNA samples (Figure 1).

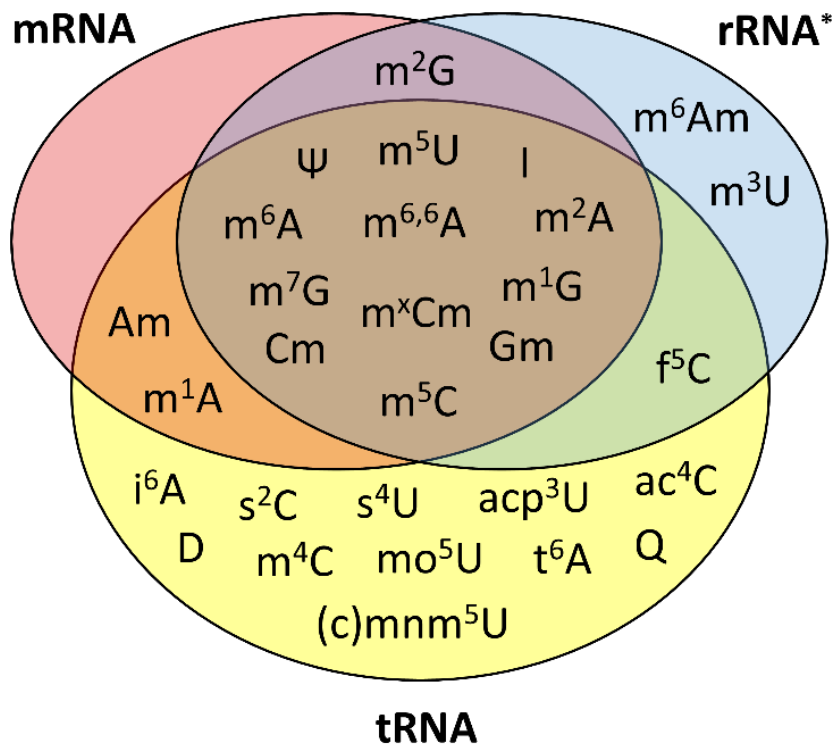

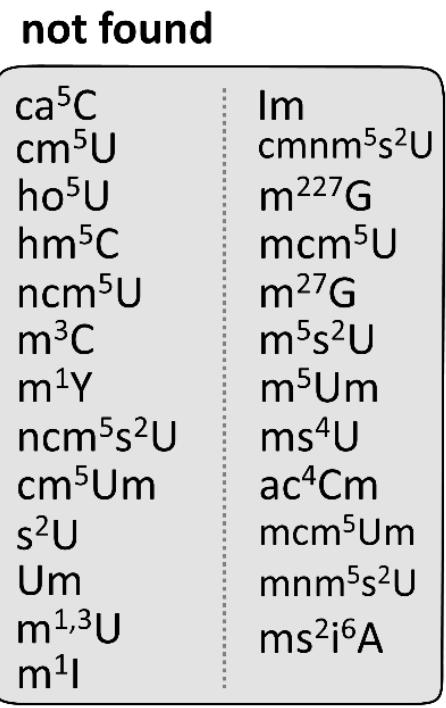

Figure 1. RNA modification profile of early log-phase E. coli MG1655. Cells were aerobically cultivated in LB medium and harvested, and total RNA was isolated. The main RNA types were separated by size exclusion chromatography and subsequent rRNA depletion with commercial kits. After enzymatic hydrolysis, mass spectrometry was used to screen for 54 known modified nucleosides. 29 modified nucleosides were found in the mRNA, rRNA*, and tRNA fractions as indicated (left), and 25 were not found (right). *The results for rRNA represent the modifications found in the rRNA+mRNA fraction after tRNA removal by SEC, where the minor contribution of mRNA to the total modification levels is neglectable due to the excessive amounts of rRNA.

\section{Preparation of samples for quantitative analysis of mRNA and rRNA modifications}

Our qualitative profiling of modifications in the three major RNA types obtained by commonly applied RNA purifications technologies revealed an unexpected high chemical diversity of modified nucleosides of mRNA in E. coli. However, the high sensitivity of the MS method depends on RNA samples with well-defined purity, because e.g., tRNA or rRNA contaminations would go unnoticed. Furthermore, it is important to mention that RNA handling itself can induce the formation of RNA modification artefacts or loss of certain modified nucleosides ${ }^{18}$. For a rigorous qualitative and quantitative assessment of mRNA modifications, both aspects need to be considered already during the preparation of bacterial mRNA for subsequent MS-based 
analysis. We decided that agarose gel electrophoresis-based size selection of RNAs is the most stringent method for successful separation of mRNA and rRNA, which bears the lowest risk for RNA modification artefact formation.

Total bacterial RNA was loaded on denaturing agarose gels, and after electrophoresis, four gel pieces per lane were excised. The RNA was extracted using a commercially available kit. According to size we obtained the following fractions: fraction 1 (23S rRNA), fraction 2 (mRNAs and noncoding RNAs of 1,700 to 2,700 bases), fraction 3 (16S rRNA) and fraction 4 (mRNAs and noncoding RNAs of 400 to 1,100 bases) (Figure 2A). The quality of each fraction was tested by chip gel electrophoresis and by running the extracted RNA on a denaturing agarose gel (Figure 2A). These controls indicated that we obtained efficient separation between the rRNA and mRNA fractions.

Due to their abundance, $16 \mathrm{~S}$ and $23 \mathrm{~S}$ rRNAs are a constant source for the contamination of mRNA modification signals ${ }^{19}$. Therefore, we used RT-qPCR and RNA deep sequencing (RNA-Seq) to analyze the composition of the mRNA-containing fractions 2 and 4 . We first determined the ratio of mRNA:rRNA using the two different internal calibrators alaS and recA for the long and short mRNA fractions, respectively. We observed at least a 1,000-fold increase in the mRNA:rRNA ratio in both fractions when compared to the total RNA samples (Figures 2B and S3A). We got a similar result for mRNA samples obtained using the commercial oligonucleotides-based kits, however, these kits appear to selectively deplete 16S rRNA while substantial amounts of $23 S$ rRNA remain (Figure S2).

A second RT-qPCR experiment focused on the possibility of a co-purification of rRNA fragments in the mRNA-containing fractions 2 and 4 . We performed RT-qPCR using primer pairs binding to three different regions of the rRNA sequences (5'-, middle and 3'-region). These results revealed that $16 S$ rRNA and, to a lesser extent, 23S rRNA had been partially degraded at the 3' end (Figure S3B). We found a contamination of fractions 2 and 4 with approximately 10\% rRNA fragments (Figure $\mathrm{S} 3 \mathrm{C})$.

To further define the purity of our mRNA fractions 2 and 4 , we subjected all four fractions as well as total RNA to deep sequencing. As expected, fraction 1 (23S rRNA) and fraction 3 (16S rRNA) contained the expected rRNA, but in addition $1.4 \%$ and $1.3 \% \mathrm{mRNA}$, respectively (Figure 2C). Worryingly, the RNA-Seq results of the total read samples revealed an mRNA:rRNA ratio of only 14:86 for fraction 2 and $16: 83$ for fraction 4 (Figure 2C), which is clearly different from our RT-qPCR data (Figure $2 \mathrm{~B})$. However, because the mRNA in a given fraction is a mixture of many different sequences with low abundance, it is likely that some mRNA targets were amplified less efficiently than the rRNAs with many of the same targets during library preparation for RNA-Seq. This factor can be compensated by removing duplicates that accumulate during the PCR amplification steps of library preparation. Taking this factor into account, we obtained an mRNA:rRNA ratio of 53:47 for fraction 2 and 58:42 for fraction 4 (Figure 2D). Reads mapping to the $23 S$ and $16 S$ rRNA sequences were distributed differently in total RNA and fractions 2 and 4 (Figure 2E). For example, reads mapping to the middle sequence of $23 S$ rRNA (700-1900 nt) were overrepresented in fraction 2, whereas reads mapping to the $3^{\prime}$ sequence (1000-1542 nt) of 16S rRNA were underrepresented in fraction 4 (Figure 2E). Considering the localization of known modifications in $23 S$ and 16 S rRNA (Figure 2E), these results were important to judge which modifications might be the result of rRNA contaminations in fractions 2 and 4.

In summary, depending on the used method, our quality controls revealed different degrees of contamination with rRNA of the mRNAenriched fractions 2 and 4 . Nevertheless, according to our RNA-Seq controls, the mRNA levels in fractions 2 and 4 were increased about 15 -fold compared with fractions 1 and 3 in the worst-case scenario and up to 50 -fold in the best-case scenario (Figure 2). 

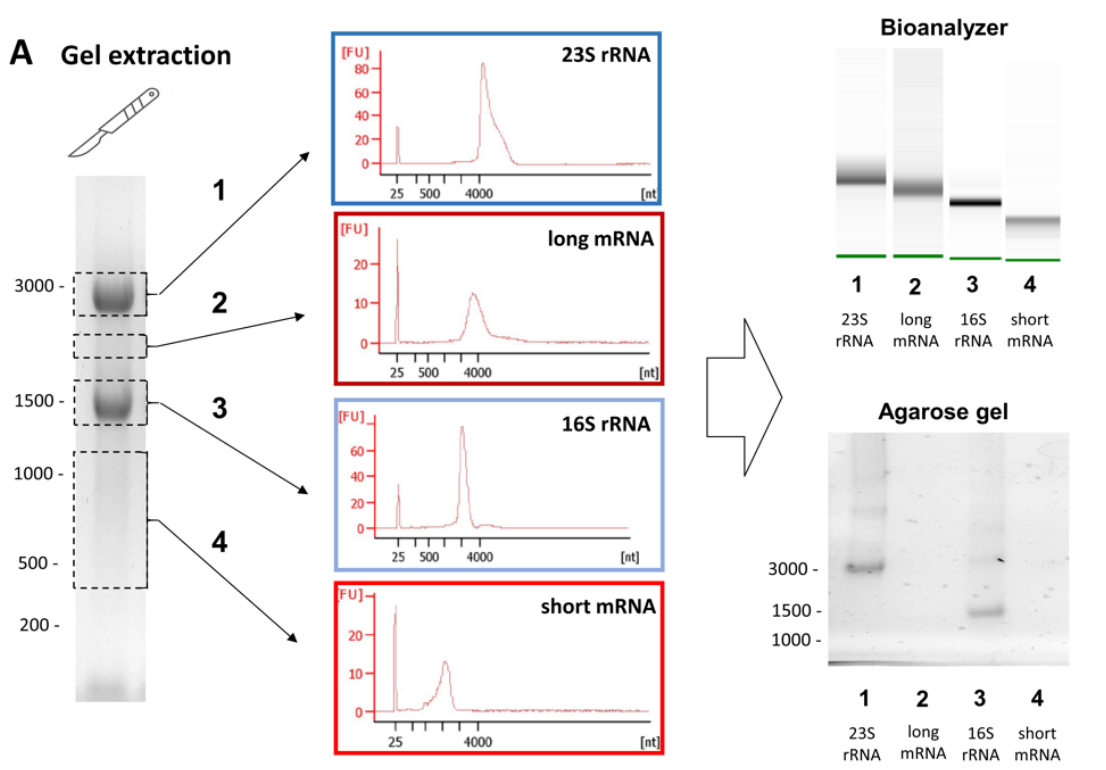

B

RT-qPCR analysis

C

$=235$ rRNA \% $=165$ rRNA $\square$ 5S rRNA $=$ tRNA $=$ mRNA

D
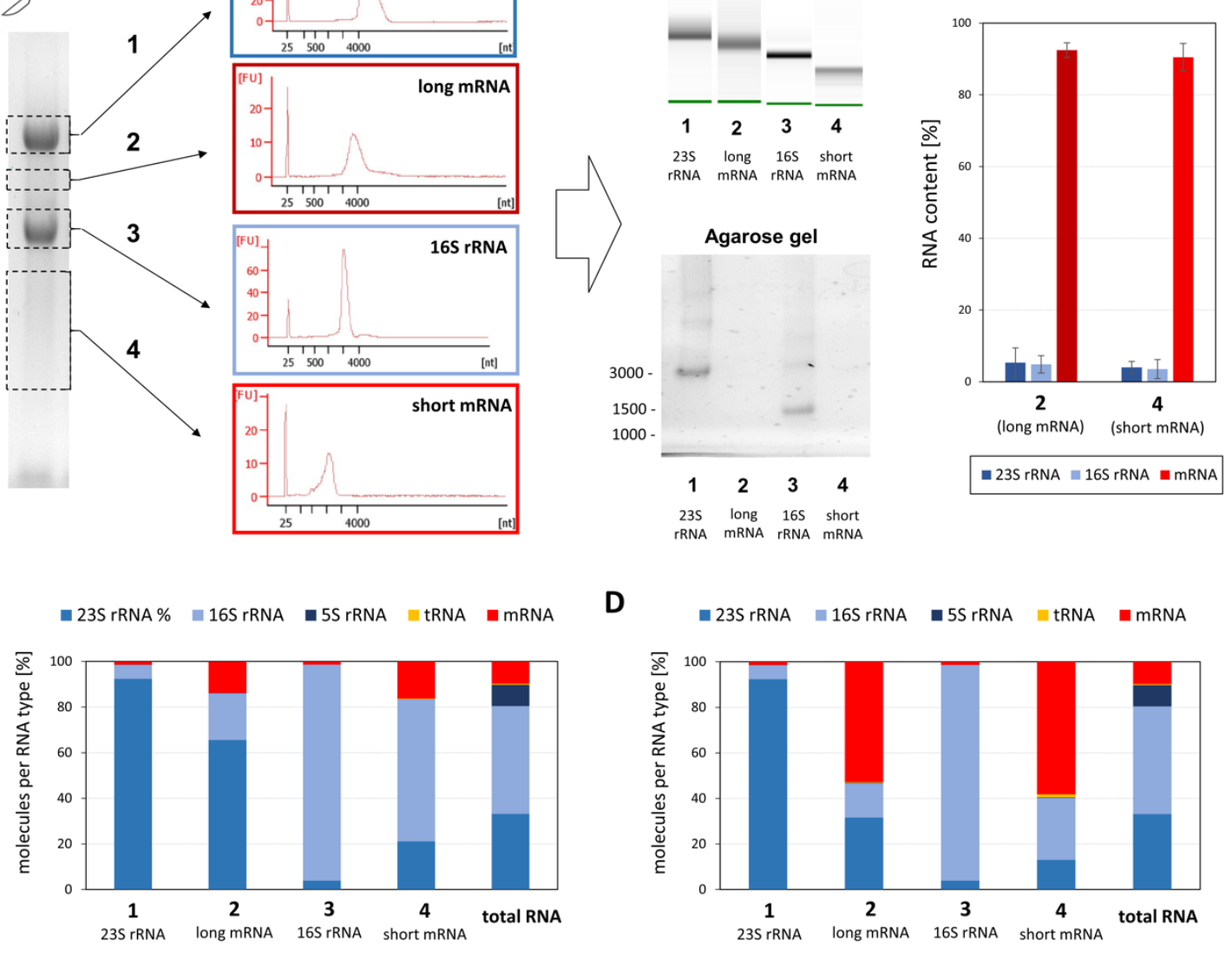

$=23 \mathrm{~S}$ rRNA $=16 \mathrm{~S}$ rRNA $=5 \mathrm{~S}$ rRNA $=$ tRNA $=\mathrm{mRNA}$

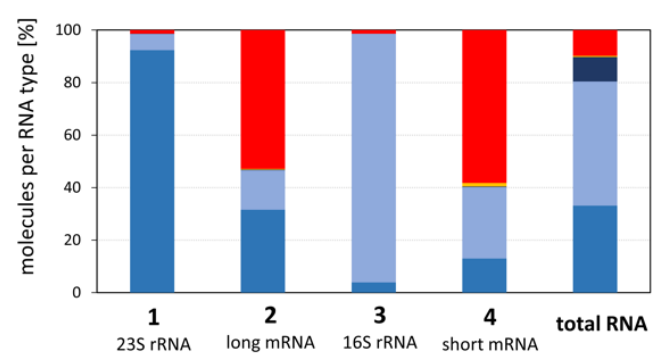

$\mathbf{E}$
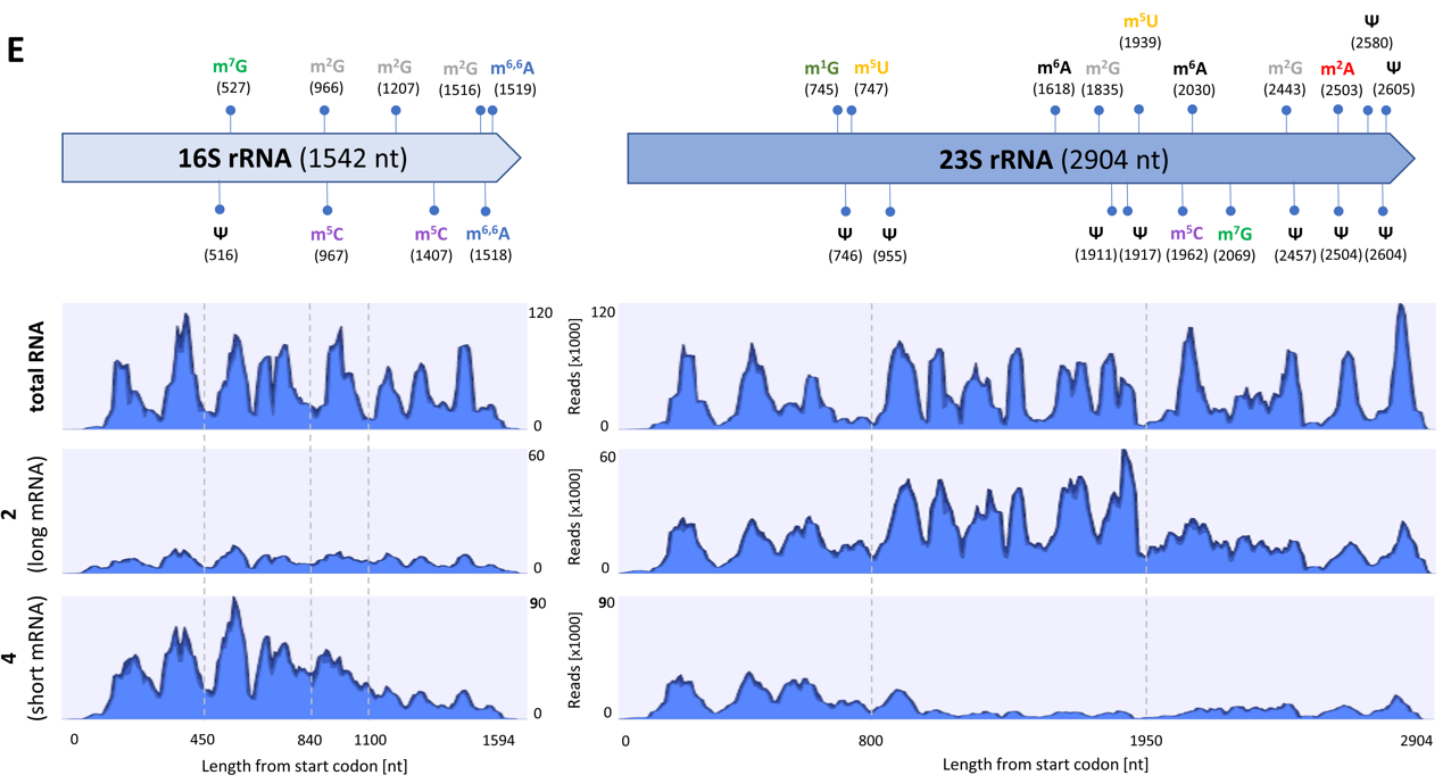

Figure 2. Analysis of RNA types from E. coli after separation by denaturing agarose gel electrophoresis. (A) After denaturing gel electrophoresis, total RNA was separated in four fractions: fraction 1 (23S rRNA), fraction 2 (mRNAs and noncoding RNAs of 1,700 to 2,700 bases), fraction 3 (16S rRNA) and fraction 4 (mRNAs and noncoding RNAs of 400 to 1,100 bases). The fractions were cut from the gel and after extraction analyzed by automated chip gel electrophoresis (Bioanalyzer, Agilent). The factions were reloaded onto an agarose gel to confirm the efficiency of separation. (B) Percentage of the major RNA types in the mRNA-enriched fractions 2 and 4 determined by RT-qPCR. Values were calculated based on an assumed ratio of $1 \% \mathrm{mRNA}$ and $90 \%$ rRNA in the total RNA (see Material and Methods for detailed description). (C) Molar ratios of major RNA types in the four fractions and the total RNA based on RNA-Seq analysis. (D) Molar ratios of major RNA types found in the four 
fractions and the total RNA based on RNA-Seq analysis after duplicate removal. (E) Schematic map of the localization of modifications in 23S rRNA and 16S rRNA of E. coli, and distribution of reads mapping to $23 S$ rRNA and 16S rRNA sequences in samples of total RNA and fractions 2 and 4. B-D represent average results of three biological replicates with error bars of standard deviation from the means in $\mathrm{B}$. E shows one representative example.

\section{Quantitative analysis of mRNA and rRNA modifications}

We moved on to quantitative LC-MS/MS analysis of the gel-extracted RNA fractions. The quantification of modifications detected in rRNA-enriched fractions 1 (23S rRNA) and 3 (16S rRNA) served as an internal control for our approach. We found $\mathrm{m}^{6,6} \mathrm{~A}$ only in $16 \mathrm{~S}$ rRNA, whereas $m^{6} A, m^{1} G, m^{5} U$, and $m^{2} A$ were found in 23S rRNA (Figures 3 and S4B, Table 1), which is in agreement with the methylation patterns reported in previous studies (reviewed $\mathrm{in}^{20}$ ). Moreover, the stoichiometry of the modifications in the 23S and 16S rRNA fractions matched with the theoretical expectations based on the number of modification sites (Figure S4B). When calculating the expected abundance, we considered the fact that 23S rRNA is twice as long as 16S rRNA as the modification abundance would be inversely proportional to the length of the molecule. This effect was well demonstrated by the observed $\sim 40 \%$ lower abundance of $\mathrm{m}^{7} \mathrm{G}$ in $23 \mathrm{~S}$ rRNA (1 site: $1.38 \%$ $\pm 0.11 \%$ ) compared to $16 \mathrm{~S}$ rRNA (1 site: $2.63 \%$ $\pm 0.07 \%$ ), reflecting a $\sim 40 \%$ difference in length between the two rRNA types (Figure 3A, Table 1).

Quantitative LC-MS/MS analysis of the gelextracted mRNA-containing fractions 2 and 4 was consistent with our qualitative results. We detected $m^{6} A, m^{6,6} A, m^{1} G, m^{7} G, m^{5} C, m^{5} U$, and $\Psi$ in both the long and short mRNA-enriched fractions 2 and 4 in stoichiometrically relevant quantities using a stable isotope-labeled internal standard from Saccharomyces cerevisiae tRNA (SILIS) ${ }^{21}$ (Figure 3A and Table 1). $m^{2} A$ was also detected in the mRNA fractions at a similar abundance as in the 23S rRNA fraction (Figure S5). However, due to the absence of $\mathrm{m}^{2} \mathrm{~A}$ in the yeast-derived SILIS, further analysis and quantitative assessment of $\mathrm{m}^{2} \mathrm{~A}$ was not possible.

Overall, our mRNA-enriched fractions 2 and 4 showed a reproducible modification profile that is different from the 23S and 16S rRNA modification profiles and quantitatively decoupled (Figure $3 \mathrm{~A}$ ). For example, $\mathrm{m}^{6} \mathrm{~A}$ is lower in fraction 2 compared to the preceding 23S rRNA fraction, whereas modifications such as $m^{7} G, m^{5} C, m^{5} U$ and $\Psi$ are higher. In contrast, $m^{6} A, m^{1} G, m^{7} G, m^{5} U$ and $\psi$ are higher in fraction 4 compared with the preceding $16 \mathrm{~S}$
rRNA fraction, whereas $\mathrm{m}^{5} \mathrm{C}$ is lower and of similar abundance as in fraction 2.

The quantification results for fractions 2 and 4 showed that $m^{6} \mathrm{~A}$ is not the most abundant mRNA modification in $E$. coli. We measured comparable amounts of $\mathrm{m}^{6} \mathrm{~A}$ (on average $1.1 \%$ ) to those published previously by Deng et al. ${ }^{13}$, but modifications such as $m^{1} G, m^{7} G, m^{5} C, m^{5} U$, and $\Psi$ had higher abundances (Table 1 ). The most abundant modification in the mRNAenriched fractions 2 and 4 was $\psi$ (approximately 12\%o). The $\mathrm{m}^{5} \mathrm{C}$ abundance detected in the fractions containing mRNAs was about $3.5 \%$. The abundance of $\mathrm{m}^{6,6} \mathrm{~A}$ was comparable to that of $\mathrm{m}^{6} \mathrm{~A}$. For several modifications, we observed different methylation levels between the two mRNAenriched fractions. In fraction 2, containing long mRNAs, we measured a 2.5-times higher $\mathrm{m}^{6} \mathrm{~A}$ abundance compared to fraction 4 , containing short mRNAs. The abundance of $\mathrm{m}^{1} \mathrm{G}$ in fraction 2 was also higher than that in fraction 4. Conversely, for $m^{7} G$, we observed a lower abundance in fraction 2 compared to that in fraction 4 (Figure $3 \mathrm{~A}$ and Table 1). For other modifications such as $\mathrm{m}^{5} \mathrm{C}$ and $\Psi$, we did not observe significant differences between the long and short mRNA-enriched fractions.

Since our quality controls have indicated the presence of rRNA contamination in fractions 2 and 4 , we assumed a worst-case scenario (using the highest degree of contamination, Figure 2C) and checked whether such contamination could be sufficient to explain the modification levels observed in the mRNAenriched fractions 2 and 4 . We calculated the abundance of each modification coming from the rRNA contamination and subtracted the value from the determined values in fractions 2 or 4 . We included in this calculation the location of the known modification sites and correlated this number with the distribution of reads mapping to the rRNA sequences (Figure 2E). Taking this worst-case scenario, the abundancies of the modifications measured in fractions 2 and 4 could not be explained with co-purified rRNAs. For example, the rRNAcontamination accounts for only about $50 \%$ of the measured abundance of $m^{7} \mathrm{G}$ and $\mathrm{m}^{6,6} \mathrm{~A}$ in fractions 2 and 4 . For modifications such as $m^{6} A$ as well as $m^{5} U$ or $\Psi$, the measured amounts in fraction 4 were higher than the assumed worst-case rRNA-contamination. 
A
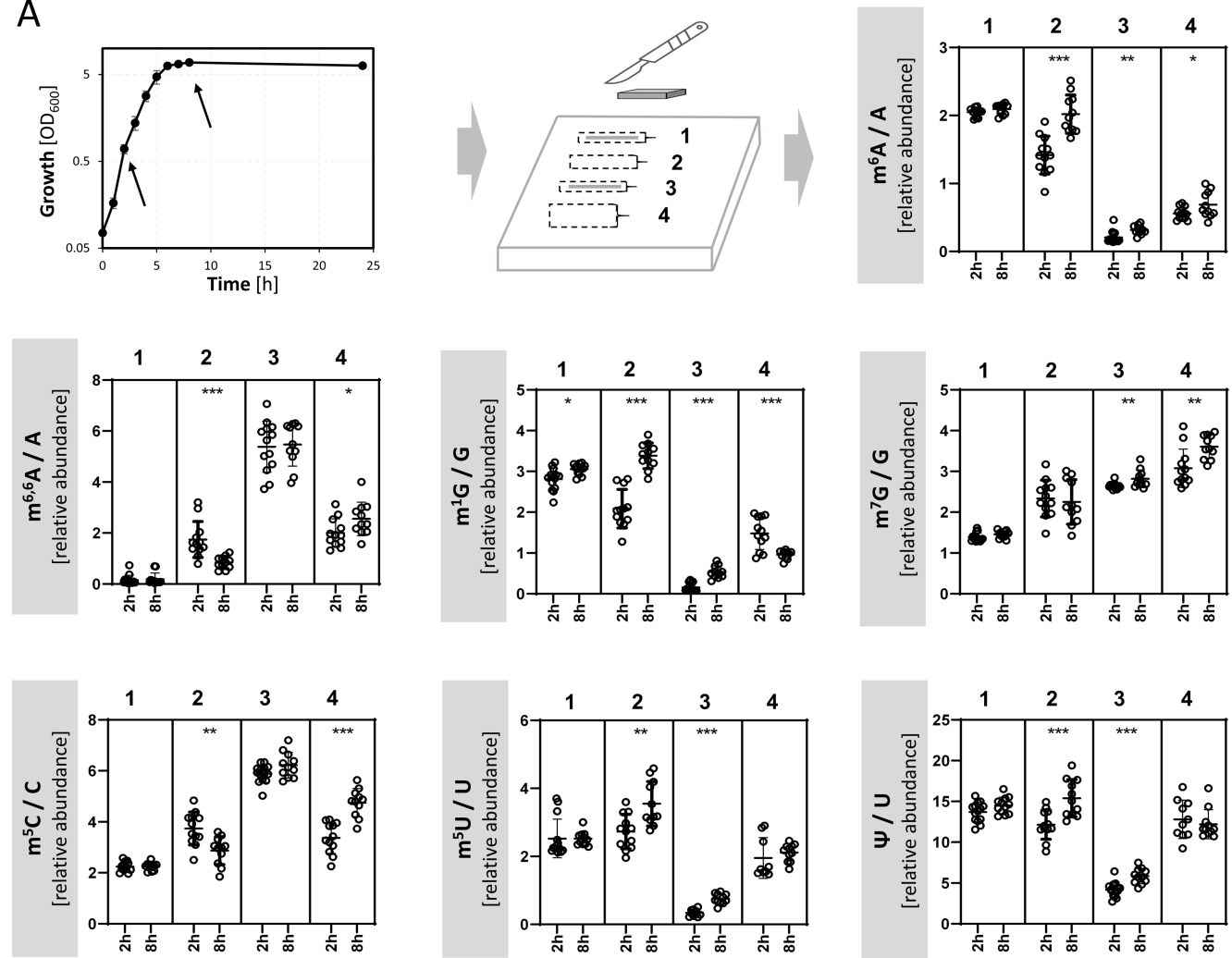

B

rRNA- depletion (kit)

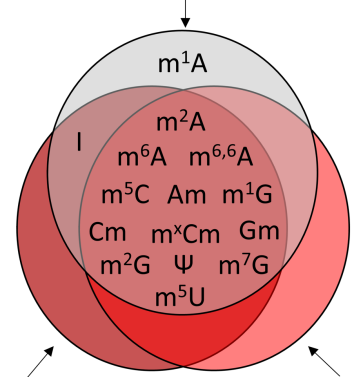

long mRNA

short mRNA

(fraction 2 - gel)

(fraction 4 - gel)

Figure 3. Quantitative analysis of modifications in RNA of $E$. coli after separation with denaturing gel electrophoresis. (A) RNA was isolated from E. coli MG1655 cells after cultivation in complex LB medium under aerobic conditions for $2 \mathrm{~h}$ (exponential growth phase) and $8 \mathrm{~h}$ (early stationary phase). Time points of RNA extraction are indicated by arrows in the growth curve. Following denaturing gel electrophoresis (see Figure 2) total RNA was separated in: fraction 1 (23S rRNA), fraction 2 (mRNAs and noncoding RNAs of 1,700 to 2,700 bases), fraction 3 (16S rRNA) and fraction 4 (mRNAs and noncoding RNAs of 400 to 1,100 bases). The fractions were cut from the gel and after rigorous quality controls, hydrolyzed and analyzed via LC-MS/MS. The relative quantities of the modified nucleosides were normalized to their respective canonical precursors. The results of at least four biological replicates are presented, each measured in technical triplicates. p-values were calculated using paired Student's t-test with ${ }^{*} \leq 0.05,{ }^{* *} \leq 0.01$, and ${ }^{* *} \leq 0.001$. (B) Comparison of the qualitative mRNA modification profiles after using two enrichment methods, the oligonucleotide-based rRNA depletion and the denaturing gel electrophoresis. 
In parallel, we subjected the same total RNAs used for gel electrophoresis of mRNA enrichment to the established oligonucleotidebased rRNA depletion protocol. Despite relying on different strategies, both approaches resulted in the qualitative identification of nearly identical mRNA modifications after LC-MS/MS analysis (Figure $3 B$ ). In addition to $m^{6} A$, both approaches identified the presence of $m^{6,6} A$, $m^{1} G, m^{2} G, m^{7} G, m^{5} C, m^{5} U, A m, G m, C m$, $\mathrm{m}^{\times} \mathrm{Cm}$ and $\Psi$ in the mRNA from $E$. coli. Inosine (I), a potential artefact derived from chemical adenosine deamination, was only detected in the rRNA-depletion approach and in the gelextracted long mRNA-enriched fraction 2, but not in fraction 4.

When comparing the quantitative results of the two approaches, we generally observed higher modification abundances in the gelextracted samples compared to those using the rRNA depletion approach (Figure S4A). Nevertheless, the results of both approaches showed similar profiles: $\Psi$ was the most abundant modification, followed by $\mathrm{m}^{5} \mathrm{C}$, and $m^{5} U$, whereas $m^{6} A$ was among the least abundant modifications found in the mRNAenriched fractions of $E$. coli. Importantly, the mRNA profile was distinct from the tRNA as well as the 23S and 16S rRNA profiles of $E$. coli (Figure S4). The clearest difference between the profiles of the three RNA types was observed in the ratios between different modifications: $m^{6,6} A: m^{5} \mathrm{C}: \mathrm{m}^{5} U: \mathrm{m}^{7} \mathrm{G}: \Psi$ ratio was $0: 0: 4: 1: 6$ in tRNA, $0: 2: 3: 1: 15$ in 23S rRNA, 5:5:0:2:3 in 16S rRNA, and 2:4:3:2:12 in mRNA (Figure S4). These ratios of RNA modifications are an additional indication that we were able to prepare substantially mRNA-enriched fractions.

In summary, although we do not know exactly to what extent the mRNA fractions are contaminated with full-length rRNAs or their various fragments, the differences in modification quantities and profiles found in rRNA and in the mRNA-enriched fractions gave us confidence that $m^{6} A$ and $m^{7} G$, but also $m^{1} G$, $m^{5} \mathrm{C}, \mathrm{m}^{6,6} \mathrm{~A} \mathrm{~m}^{5} \mathrm{U}$, and $\Psi$ are modifications present in the mRNA of $E$. coli.

Table 1. Quantitative LC-MS/MS analysis of the fractions 1-4 (Figure 3A), tRNA after SEC, and mRNA after rRNA depletion isolated from total RNA of $E$. coli MG1655. Cells were cultivated in LB medium for $2 \mathrm{~h}$ (exponential growth phase) or $8 \mathrm{~h}$ (stationary phase). The values represent the quantities of modified nucleosides after normalization to their respective canonical precursors (per 1,000 nucleosides). Results represent the mean and standard deviation of at least three biological replicates measured in technical triplicates. Theoretical values for $16 \mathrm{~S}$ and 23S rRNA are shown for comparison.

\begin{tabular}{|c|c|c|c|c|c|c|c|c|c|}
\hline Time & RNA type & $m^{6} A$ & $m^{2} A$ & $m^{6.6} A$ & $m^{1} G$ & $m^{7} G$ & $m^{5} \mathrm{C}$ & $m^{5} U$ & $\Psi$ \\
\hline $2 \mathrm{~h}$ & $\begin{array}{l}\text { fraction } 1 \\
(23 S \text { rRNA) }\end{array}$ & $\begin{array}{c}1.85 \\
\pm 0.42\end{array}$ & $\begin{array}{c}1.33 \\
\pm 0.13\end{array}$ & $\begin{array}{c}0.16 \\
\pm 0.19\end{array}$ & $\begin{array}{c}2.81 \\
\pm 0.27\end{array}$ & $\begin{array}{c}1.38 \\
\pm 0.11\end{array}$ & $\begin{array}{c}2.16 \\
\pm 0.35\end{array}$ & $\begin{array}{c}2.52 \\
\pm 0.57\end{array}$ & $\begin{array}{r}13.71 \\
\pm 1.21\end{array}$ \\
\hline $8 \mathrm{~h}$ & $\begin{array}{l}\text { fraction } 1 \\
\text { (23S rRNA) }\end{array}$ & $\begin{array}{c}2.09 \\
\pm 0.07\end{array}$ & $\begin{array}{c}1.30 \\
\pm 0.10\end{array}$ & $\begin{array}{c}0.19 \\
\pm 0.24\end{array}$ & $\begin{array}{c}3.05 \\
\pm 0.14\end{array}$ & $\begin{array}{c}1.46 \\
\pm 0.09\end{array}$ & $\begin{array}{c}2.45 \\
\pm 0.69\end{array}$ & $\begin{array}{c}2.52 \\
\pm 0.20\end{array}$ & $\begin{array}{r}14.50 \\
\pm 1.01\end{array}$ \\
\hline $2 \mathrm{~h}$ & $\begin{array}{l}\text { fraction } 2 \\
\text { (long mRNA) }\end{array}$ & $\begin{array}{c}1.42 \\
\pm 0.28 \\
\end{array}$ & $\begin{array}{c}1.08 \\
\pm 0.18 \\
\end{array}$ & $\begin{array}{c}1.75 \\
\pm 0.70 \\
\end{array}$ & $\begin{array}{c}2.09 \\
\pm 0.47 \\
\end{array}$ & $\begin{array}{c}2.34 \\
\pm 0.45 \\
\end{array}$ & $\begin{array}{c}3.74 \\
\pm 0.65 \\
\end{array}$ & $\begin{array}{c}2.73 \\
\pm 0.51 \\
\end{array}$ & $\begin{array}{r}12.15 \\
\pm 1.78 \\
\end{array}$ \\
\hline $8 \mathrm{~h}$ & $\begin{array}{l}\text { fraction } 2 \\
\text { (long mRNA) }\end{array}$ & $\begin{array}{c}2.02 \\
\pm 0.28 \\
\end{array}$ & $\begin{array}{c}1.30 \\
\pm 0.41 \\
\end{array}$ & $\begin{array}{c}0.84 \\
\pm 0.24\end{array}$ & $\begin{array}{c}3.38 \\
\pm 0.32\end{array}$ & $\begin{array}{c}2.25 \\
\pm 0.55\end{array}$ & $\begin{array}{c}2.87 \\
\pm 0.55 \\
\end{array}$ & $\begin{array}{c}3.55 \\
\pm 0.66\end{array}$ & $\begin{array}{r}15.40 \\
\pm 2.28\end{array}$ \\
\hline $2 \mathrm{~h}$ & $\begin{array}{l}\text { fraction } 3 \\
(16 \mathrm{~S} \text { rRNA) }\end{array}$ & $\begin{array}{c}0.19 \\
\pm 0.09 \\
\end{array}$ & $\begin{array}{c}0.10 \\
\pm 0.03\end{array}$ & $\begin{array}{c}5.32 \\
\pm 0.97\end{array}$ & $\begin{array}{c}0.14 \\
\pm 0.11\end{array}$ & $\begin{array}{c}2.63 \\
\pm 0.07\end{array}$ & $\begin{array}{r}5.82 \\
\pm 0.35\end{array}$ & $\begin{array}{c}0.33 \\
\pm 0.10\end{array}$ & $\begin{array}{c}4.07 \\
\pm 0.91\end{array}$ \\
\hline $8 \mathrm{~h}$ & $\begin{array}{l}\text { fraction } 3 \\
(16 S \text { rRNA) }\end{array}$ & $\begin{array}{c}0.32 \\
\pm 0.07 \\
\end{array}$ & $\begin{array}{c}0.23 \\
\pm 0.03 \\
\end{array}$ & $\begin{array}{c}5.47 \\
\pm 0.84 \\
\end{array}$ & $\begin{array}{c}\mathbf{0 . 5 3} \\
\pm 0.15 \\
\end{array}$ & $\begin{array}{r}2.82 \\
\pm 0.22 \\
\end{array}$ & $\begin{array}{c}6.22 \\
\pm 0.50 \\
\end{array}$ & $\begin{array}{c}0.75 \\
\pm 0.15 \\
\end{array}$ & $\begin{array}{c}5.85 \\
\pm 0.94 \\
\end{array}$ \\
\hline $2 \mathrm{~h}$ & $\begin{array}{l}\text { fraction } 4 \\
\text { (short mRNA) }\end{array}$ & $\begin{array}{c}0.56 \\
\pm 0.09 \\
\end{array}$ & $\begin{array}{c}1.23 \\
\pm 0.36 \\
\end{array}$ & $\begin{array}{c}\mathbf{2 . 0 1} \\
\pm 0.55\end{array}$ & $\begin{array}{c}1.48 \\
\pm 0.40\end{array}$ & $\begin{array}{c}3.08 \\
\pm 0.47\end{array}$ & $\begin{array}{c}3.37 \\
\pm 0.61 \\
\end{array}$ & $\begin{array}{c}2.12 \\
\pm 0.77\end{array}$ & $\begin{array}{l}11.94 \\
\pm 2.94\end{array}$ \\
\hline \multirow[t]{3}{*}{$8 \mathrm{~h}$} & $\begin{array}{l}\text { fraction } 4 \\
\text { (short mRNA) }\end{array}$ & $\begin{array}{c}0.69 \\
\pm 0.19 \\
\end{array}$ & $\begin{array}{c}1.16 \\
\pm 0.21\end{array}$ & $\begin{array}{c}2.55 \\
\pm 0.66\end{array}$ & $\begin{array}{c}0.96 \\
\pm 0.10\end{array}$ & $\begin{array}{c}3.61 \\
\pm 0.29\end{array}$ & $\begin{array}{c}4.75 \\
\pm 0.55 \\
\end{array}$ & $\begin{array}{c}2.12 \\
\pm 0.25\end{array}$ & $\begin{array}{r}12.21 \\
\pm 1.78\end{array}$ \\
\hline & $\begin{array}{l}\text { 23S rRNA } \\
\text { (theoretical) }\end{array}$ & 2.62 & 1.31 & 0 & 1.10 & 1.10 & 1.57 & 3.30 & 16.60 \\
\hline & $\begin{array}{l}\text { 16S rRNA } \\
\text { (theoretical) }\end{array}$ & 0 & 0 & 5.14 & 0 & 2.06 & 5.68 & 0 & 3.17 \\
\hline $2 \mathrm{~h}$ & tRNA & $\begin{array}{c}1.69 \\
\pm 0.20 \\
\end{array}$ & NA & $\begin{array}{c}\mathbf{0 . 4 4} \\
\pm 0.10 \\
\end{array}$ & $\begin{array}{r}7.46 \\
\pm 0.30 \\
\end{array}$ & $\begin{array}{r}25.55 \\
\pm 0.56 \\
\end{array}$ & $\begin{array}{c}0.34 \\
\pm 0.08 \\
\end{array}$ & $\begin{array}{l}97.14 \\
\pm 1.71 \\
\end{array}$ & $\begin{array}{l}136.29 \\
\pm 4.04 \\
\end{array}$ \\
\hline $2 \mathrm{~h}$ & $\begin{array}{l}\text { mRNA (rRNA } \\
\text { depletion) }\end{array}$ & $\begin{array}{c}0.50 \\
\pm 0.15\end{array}$ & $\begin{array}{c}1.44 \\
\pm 0.08 \\
\end{array}$ & $\begin{array}{r}1.18 \\
\pm 0.77\end{array}$ & $\begin{array}{c}0.85 \\
\pm 0.29\end{array}$ & $\begin{array}{c}0.92 \\
\pm 0.22\end{array}$ & $\begin{array}{c}1.17 \\
\pm 0.66 \\
\end{array}$ & $\begin{array}{c}1.35 \\
\pm 0.83\end{array}$ & $\begin{array}{r}\mathbf{5 . 8 8} \\
\pm 1.83 \\
\end{array}$ \\
\hline
\end{tabular}




\section{Dynamics of mRNA modification}

In eukaryotes, mRNA methylation is a dynamic, reversible process that has regulatory functions and involves a complex system of writers, readers, and erasers ${ }^{8,22}$. Therefore, we were interested in whether the newly identified modifications of bacterial mRNA change in relative abundance depending on the growth phase. We compared the modification patterns between the early exponential growth phase $(2 \mathrm{~h})$ and the stationary phase (8 h) (Figure 3A). We observed statistically significant increases in $m^{6} \mathrm{~A}, \mathrm{~m}^{1} \mathrm{G}, \mathrm{m}^{5} \mathrm{C}$, and $\Psi$, and a significant decrease in $m^{6,6} A$ in some of the mRNAenriched fractions of stationary phase cells compared with mRNA derived from the exponential growth phase cells. Whereas for $\mathrm{m}^{6} \mathrm{~A}$ the increase of modification abundance towards the stationary phase was observed in fractions 2 and 4 , for $m^{1} G$ and $\Psi$, we observed an increase only in fraction 2 , and for $\mathrm{m}^{5} \mathrm{C}$ only in fraction 4.

In contrast, the abundances of rRNA modifications in $E$. coli between exponential and stationary phase cells were mostly unchanged, as shown by the semi-quantitative analysis of fractions 1 and 3 (Figure 3A). We only measured a small increase in the abundance of $m^{6} A, m^{1} G$, and $\Psi$ in the $16 S$ rRNA-containing fraction 3 of stationary phase cells. However, for example, $m^{6} A$ is not known to exist in 16S rRNA, and the changes in the measured amounts are similar to the changes observed for the mRNA-enriched fractions 2 and 4 . Therefore, it is likely that these results hail from a co-purification of mRNAs of the same size.

Therefore, we also studied growth phasedependent changes of the mRNA+rRNA fractions obtained by size exclusion chromatography (Figure S6). For $\mathrm{m}^{6} \mathrm{~A}$ and $\mathrm{m}^{1} \mathrm{G}$, we measured a steady increase, with the highest values observed after 24 hours of growth (representing the late stationary phase). In contrast, for $\mathrm{m}^{5} \mathrm{C}$, we observed a slight decrease in abundance over the course of growth of $E$. coli. For $\mathrm{m}^{7} \mathrm{G}$, the abundance remained nearly unchanged over the measured time course, but there was a temporal peak during the transition of $E$. coli to stationary phase. Overall, the mRNA+rRNA fractions also revealed growth phase dependent alterations in the RNA modifications.

Next, we tested whether the modification profile of mRNA in E. coli changes under the influence of external factors such as acid stress or oxygen limitation. We cultivated cells in tryptone-based (LB) medium at $\mathrm{pH} 7.6$ and pH 5.4 under aerobic or microaerobic (oxygen limitation) conditions, separated total RNA using denaturing gel electrophoresis, and compared the absolute abundance of RNA modifications during the exponential growth phase and shortly before the transition into the stationary phase. We found that most of the epitranscriptomic marks remained at similar abundances independent of oxygen limitation. Changes of the mRNA modifications observed during the transition from exponential growth to stationary phase under aerobic conditions (Figure 3A) were also found under oxygen limiting conditions (Figure S7). Specifically, we observed a statistically significant increase in $m^{6} A, m^{1} G$, and $m^{5} U$ and a decrease in $m^{5} C$ in the long mRNA-enriched fraction 4 of stationary phase cells both under aerobic and microaerobic conditions.

However, we noted a sharp decrease for the $\mathrm{m}^{6,6} \mathrm{~A}$ levels in $16 \mathrm{~S}$ rRNA upon oxygen limitation. During aerobic growth the $m^{6,6} A$ abundance in fraction 3 (16S rRNA) was 5.8\%o $\pm 0.35 \%$ (Figure $3 \mathrm{~A}$ ), and under microaerobic conditions there was a more than threefold reduction to $1.51 \%$ \% $0.35 \%$ o (Figure 4 ). These results indicate a correlation between environmental stress adaptation and rRNA modification in E. coli.

Comparison of cells cultivated under physiological condition ( $\mathrm{pH}$ 7.6) and acid stress (pH 5.4) revealed stress-specific changes for two modifications: $\mathrm{m}^{6,6} \mathrm{~A}$ and $\Psi$ (Figure 4). The cultivation of $E$. coli at $\mathrm{pH} 5.4$ led to a threefold reduction in the $m^{6,6} A$ abundance in fraction 3 (16S rRNA) and to a smaller extent in fraction 2 (long mRNAs). An even more dramatic effect was observed for $\Psi$. Cultivation of $E$. coli under aerobic or microaerobic conditions at $\mathrm{pH} 5.4$ resulted in a loss of $\Psi$ in fraction 4 (short mRNAs) (Figure 4). This effect was targetspecific and not caused by a general issue with RNA as the levels of other modifications in this fraction were not affected (data not shown). In addition, the $\Psi$ level of fraction 2 (long-mRNAs) was not significantly altered by acid stress. These results suggest repression of a specific subset of mRNAs between 400 and 1,200 nt under acid stress, which are otherwise targets of $\Psi$ modification. 


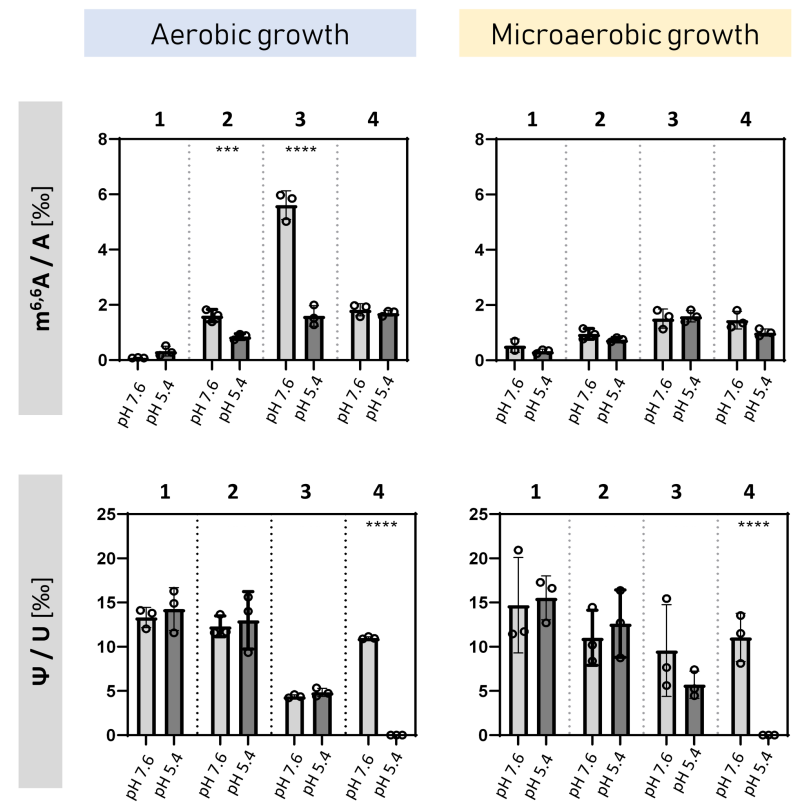

Figure 4. Impact of oxygen limitation and acid stress on the RNA modifications in E. coli. Changes in the absolute levels of modifications in mRNA and rRNA enriched fractions 1-4 (see Figure 2) extracted after denaturing gel electrophoresis of total RNA from E. coli MG11655 cells cultivated in complex LB medium at pH 7.6 or pH 5.4 under aerobic or microaerobic conditions. Fraction 1, $23 \mathrm{~S}$ rRNA; fraction 2, RNAs 1,700 to 2,700 nts; fraction 3, $16 \mathrm{~S}$ rRNA; fraction 4, RNAs 400 to $1,100 \mathrm{nts}$. The results of three biological replicates are presented. $p$-values were calculated by paired Student's t-test with ${ }^{*} \leq 0.05,{ }^{* *} \leq 0.01$, and ${ }^{* * *} \leq 0.001$.

\section{DISCUSSION}

In this study, we analyzed the mRNA modification profile of the model bacterium $E$. coli MG1655. In addition to the known modification $\mathrm{m}^{6} \mathrm{~A}$, we provide evidence for the presence of previously undescribed modifications in the mRNA of E. coli. Using two different mRNA enrichment methods in combination with targeted LC-MS/MS, we obtained evidence that modifications previously found only in the rRNA and/or tRNA of $E$. coli, such as $m^{6,6} A, m^{1} G, m^{5} C, m^{7} G, m^{5} U$, and $\Psi$ also occur as mRNA modifications. $m^{5} \mathrm{C}, \mathrm{m}^{7} \mathrm{G}$, and $\Psi$ have been previously described as mRNA modifications in eukaryotes, and our quantitative MS analysis revealed comparable levels of these modifications in bacterial mRNA. For example, $\mathrm{m}^{5} \mathrm{C}$ has been found in the mRNA of the archaeon $S$. solfataricus ${ }^{14}$ and in human mRNA with an abundance of $4.3 \%{ }^{23}$, which is similar to the abundances of $3.25 \%$ o $\pm 0.84 \%$ o (fraction 2, long mRNA) and $3.65 \%$ $\pm 0.33 \%$ (fraction 4, short mRNA) measured in this study (Figure 3A). Likewise, the determined abundance of $\Psi$ in the mRNA of $E$. coli $(1 \%)$ was comparable with the levels of $0.2 \%-0.6 \%$ that have been reported for human mRNA ${ }^{24}$, and the abundance of $\mathrm{m}^{7} \mathrm{G}$ in the mRNA of $E$. coli $\left(2 \% \%_{0}-3 \%\right)$ was comparable to the abundance of $4.5 \%$ of $\mathrm{m}^{7} \mathrm{G}$ found in human mRNA $^{25}$. In mitochondria, which have $70 \mathrm{~S}$ ribosomes as prokaryotes, $\Psi$ is also found in the $\mathrm{mRNA}^{26}$. A previous screen found no evidence for internal $\mathrm{m}^{7} \mathrm{G}$ modifications in $E$. coli's mRNA ${ }^{27}$, suggesting that our result might reflect a capping modification, similar to the $\mathrm{m}^{7} \mathrm{G}$ cap at the $5^{\prime}$ end of mRNA in eukaryotes ${ }^{28}$. Hence, our work implies a high complexity of mRNA modifications in E. coli, which resembles the profiles previously observed in eukaryotic species $^{7,4}$. Future studies should focus on identifying the enzymes involved in bacterial mRNA modification and on clarifying whether certain mRNA structures are also substrate of the thus far known RNA methyltransferases.

We also show that the abundance of modifications such as $m^{6} A, m^{1} G, m^{5} C$, and $m^{5} U$ in mRNA changes during the growth of $E$. coli. Moreover, we observed clear effects resulting from acid stress on the quantity of $\Psi$ in short mRNAs from $E$. coli. Since the quantity of $\Psi$ in the long mRNAs was not changed, it is suggested that a set of genes, which is modified under non-stress conditions, is repressed under acid stress. Variation in mRNA modification levels during different stages of development has been previously observed in mammalian 
cells, and disruption of the plasticity of RNA modification leads to severe defects in tissue development and homeostasis ${ }^{6}$. Additionally, the presence of $\Psi$ in mRNA has been shown to increase the mRNA half-life in the parasite Toxoplasma gondii ${ }^{4}$.

A potential regulatory function of the $E$. coli mRNA methylation status is supported by the observed different abundances of modifications in fractions containing long and short mRNA, respectively. If a modification is present in all mRNAs in equal amounts per molecule, as is the case for a capping modification, for example, a lower abundance would be expected in longer mRNAs. However, we observed the opposite scenario, namely higher abundances of $\mathrm{m}^{6} \mathrm{~A}$ and $m^{1} G$ in fraction 2 (long mRNAs) compared with fraction 4 (short mRNAs) (Figure 3A), suggesting that these may be gene-specific modifications that could affect specific processes within the cell.

Previously, analysis of the modification profile of bacterial mRNA has been limited by the lack of reliable methods for its purification and quantification. In this work, we validated a simple and low-cost method with the potential to overcome some of the existing difficulties. One of the main advantages of our gel extraction approach is the direct, simultaneous separation of different RNA types, which allows a comparison of RNA fractions that underwent identical chemical treatment. Hence, it avoids possible biases due to the usage of different separation methods for each RNA type, primer selection, or low antibody specificity. For example, we observed a drastic reduction of $\psi$ levels only in the short mRNA-enriched fraction 4 under acid stress. Since $\Psi$ is well distributed along the sequences of both 23S and 16S rRNA (Figure 2E), the unchanged levels of other modifications in fraction 4 together with the unchanged $\Psi$ levels in the other three fractions revealed that under this condition the absence of $\Psi$ is not a result of changes in the rRNA modification levels or different levels of rRNAcontamination in this fraction. In addition, the simultaneous measurement of multiple modifications allows the creation of modification profiles (Figure S3), enabling the assessment of possible contamination with tRNA. For examples, the $m^{6,6} A: m^{5} \mathrm{C}: m^{5} U: m^{7} G: \Psi$ ratio of tRNA differed substantially from the ratio in the mRNA-enriched fractions. Yet, some of the challenges for bacterial mRNA purification remain, and the contamination of mRNA fractions with rRNA cannot be avoided and is thus the major limitation of our purification platform.

Taken together, our results show that mRNA modification is not a specific regulatory feature of eukaryotes but also appears to have a regulatory function in prokaryotes. In bacteria, which exhibit rapid mRNA turnover and no compartmentalization, alteration of subsets of functionally related mRNAs with different modifications that specifically affect mRNA stability or translation may be an efficient way to prioritize certain cellular programs.

\section{MATERIAL AND METHODS}

Strains and growth conditions - E. coli K-12 MG1655 and E. coli BW25113 $\Delta$ trmN carrying a chromosomal deletion of $t r m N^{29}$ were used. All strains were grown in LB medium $(10 \mathrm{~g} / \mathrm{L}$ tryptone, $5 \mathrm{~g} / \mathrm{L}$ yeast extract, and $10 \mathrm{~g} / \mathrm{L} \mathrm{NaCl}$, $\mathrm{pH}$ 7.6) overnight. Cells from the overnight culture were used to inoculate fresh LB medium or LM-MES medium (LB plus $0.1 \mathrm{M}$ MES, $\mathrm{pH}$ 5.4). Bacteria were grown under agitation ( 200 $\mathrm{rpm}$ ) at $37^{\circ} \mathrm{C}$, and growth was monitored over time by measuring the optical density at $600 \mathrm{~nm}$ $\left(\mathrm{OD}_{600}\right)$. For microaerobic conditions, the cells were cultivated without shaking in closed, full vessels without access to air (Schott Duran bottles GL45, Jena, Germany).

Total RNA purification - RNA was isolated using the $\mathrm{PCl}$ protocol ${ }^{30}$ with modifications. Cell pellets corresponding to $0.5 \mathrm{~g}$ (wet weight) were washed in $1 \mathrm{~mL}$ of ice-cold AE buffer (20 mM sodium acetate buffer, $\mathrm{pH}$ 5.2, $1 \mathrm{mM}$ EDTA) and resuspended in $500 \mu \mathrm{L}$ of the same buffer. Then, $500 \mu \mathrm{L}$ of pre-warmed $\mathrm{PCl}$ for RNA extraction (Carl Roth, Karlsruhe, Germany) and $25 \mu \mathrm{L}$ of $10 \%(\mathrm{w} / \mathrm{v})$ SDS were added, and the mixture was incubated for $5 \mathrm{~min}$ at $60^{\circ} \mathrm{C}$ under vigorous agitation. Samples were cooled on ice for $2 \mathrm{~h}$ and centrifuged at $16,000 \times g$ for $1 \mathrm{~h}$. The supernatant was transferred to phase-lock tubes (Phase Lock Gel, QuantaBio, USA), and 1.0 volume of $\mathrm{PCl}$ and 0.1 volume of $3 \mathrm{M}$ sodium acetate $(\mathrm{pH} 5.2)$ were added before centrifugation for $15 \mathrm{~min}$. The supernatant was collected, mixed with 2.3 volumes of ethanol, and placed in a freezer at $-80^{\circ} \mathrm{C}$ overnight. After centrifugation at $16,000 \times g$ for $1 \mathrm{~h}$, the supernatant was discarded, and the pellet was washed twice with $70 \%(\mathrm{v} / \mathrm{v})$ ethanol, dried, and resuspended in $100 \mu \mathrm{L}$ of RNase-free water. After treatment of the samples with RNase-free DNase (Roche) according to the manufacturer's protocol, the samples were purified with another round of precipitation. The integrity of RNA was assessed by chip gel electrophoresis (Bioanalyzer 2100, RNA Nano chip kit, Agilent, Waldbronn). To evaluate the extent of DNA contaminations, the RNA preparation samples were tested by 
spectroscopic measurements (Nanodrop One) and $\mathrm{qPCR}$.

RNA separation with size exclusion chromatography - The separation of tRNA by size exclusion chromatography (SEC) was performed as described previously ${ }^{31}$ with minor modifications. Briefly, total RNA was loaded on a Thermo Scientific UltiMate 3000 LC system equipped with a diode array detector set to 260 $\mathrm{nm}$, an autosampler, a column thermostat $\left(60^{\circ} \mathrm{C}\right)$, and a fraction collector. A size exclusion column (Agilent Bio SEC-3, $3 \mu \mathrm{m}, 300 \AA$, $7.8 \times$ $300 \mathrm{~mm}$, Agilent, Waldbronn) allowed the collection of the RNA fractions after isocratic elution with $100 \mathrm{mM}$ ammonium acetate at $\mathrm{pH}$ 7. The peaks representing the mRNA+rRNA fraction as well as the tRNA fraction were collected and concentrated in a vacuum concentrator (Eppendorf Concentrator 5301). 5 $\mathrm{M} \mathrm{NH}_{4} \mathrm{OAc}$ was added to a final concentration of $0.5 \mathrm{M}$, and after addition of $2 \times$ Vol. ice-cold ethanol $(100 \%)$, the RNA was precipitated at $-20^{\circ} \mathrm{C}$ overnight. After centrifugation at 12,000 $\times g$ for 30 min at $4^{\circ} \mathrm{C}$, the RNA pellet was subjected to an additional ethanol $(80 \%$, v/v) wash step to verify the complete removal of the ammonium acetate and was then resuspended in pure water. The quality of the isolated tRNA was verified with chip gel electrophoresis (BioAnalyzer 2100, RNA Pico chip, Agilent, Waldbronn), RT-qPCR analysis, agarose gel electrophoresis, and usage of the $\Delta t r m N$ deletion mutant. RNA concentration was determined by NanoDrop ND1000 spectrophotometer (peqlab, Germany).

Gel electrophoresis and RNA extraction For gel electrophoretic extraction of RNA, denaturing $1.2 \%(\mathrm{w} / \mathrm{v})$ agarose gels (agarose Serva, Germany), $20 \mathrm{mM}$ MOPS, 1.1\% (v/v) formaldehyde (dissolved in DEPC-treated water) were used. Before loading $10 \mu \mathrm{g}$ of RNA, each sample was mixed 1:1 with sample buffer $[64 \%(\mathrm{v} / \mathrm{v})$ desalted formamide, $8.35 \%(\mathrm{v} / \mathrm{v})$ formaldehyde, $26 \mathrm{mM}$ MOPS, and $0.05 \%$ (v/v) ethidium bromide]. After the addition of $1 / 10$ volume RNA-marker [50\% (v/v) glycerol, $1 \mathrm{mM}$ EDTA, bromophenol blue, and xylene cyanol], the samples were denatured at $65^{\circ} \mathrm{C}$ for $5 \mathrm{~min}$, followed by immediate cooling on ice. The gels were run in running chambers (Bio-Rad) using $20 \mathrm{mM}$ MOPS as a running buffer at $5 \mathrm{~V} / \mathrm{cm}$ for $3 \mathrm{~h}$. As a size reference, the RiboRuler high range RNA ladder (Thermo Scientific) was used. RNA fragments with sizes from 3,200 to 2,800 nt (23S rRNA), 2,700 to 1,700 nt (long mRNAs), 1,600 to $1,400 \mathrm{nt}$ (16S rRNA), and 1,100 to 400 nt (short mRNAs) were cut from the gel, leaving physical space between each of them. Cutting was documented before and after the excision of the fragments. RNA was isolated from the gel fragments with a commercially available kit $\mathrm{Hi}$ Yield Gel/PCR DNA Fragment Extraction Kits, Suedlabor Gauting, Germany). Elution from the column was performed in two consecutive steps using $25 \mu \mathrm{L}$ water. The quality of each fraction was analyzed using chip gel electrophoresis (Bioanalyzer 2100, RNA Pico chip kit, Agilent, Waldbronn) and another denaturing agarose gel electrophoresis. The efficiency of RNA separation was tested using Bioanalyzer chip electrophoresis and RT-qPCR.

Oligonucleotide-based depletion of rRNA After removal of tRNA and small noncoding RNAs by SEC, the remaining mRNA+rRNA mixture was subjected to two consecutive rounds of rRNA depletion according to the manufacturer's protocol for oligonucleotidebased depletion of rRNA (RiboPOOL oligo pool for E. coli, siTOOLS, Martinsried, Germany). The efficiency of rRNA depletion was tested by Bioanalyzer chip electrophoresis and RT-qPCR.

RT-qPCR analysis - For RT-qPCR analysis, equal amounts of the isolated total RNA or the isolated RNA fractions were converted to CDNA with the iScript Advanced Script (Bio-Rad) according to the manufacturer's protocol. The samples were mixed with SsoAdvanced Univ SYBR Green Supermix (Bio-Rad), dispensed in triplicate into a 96-well PCR plate (Bio-Rad), and subjected to qPCR in a Bio-Rad CFX realtime cycler (see Table S1 for primers). For internal calibration, the data were evaluated using the $\Delta \Delta C$ T method $^{33}$ using rRNA and recA and alaS.

Analysis of mRNA enrichment by RT-qPCR - To evaluate the level of RNA separation and mRNA enrichment in the mRNA fractions extracted after denaturing gel electrophoresis (fractions 2 and 4) and after oligonucleotidebased rRNA depletion, the ratios of mRNA:16S rRNA and mRNA:23S rRNA were determined by RT-qPCR. To calculate the level of rRNA removal, the mRNA:rRNA ratios before (total RNA or the mRNA+rRNA fraction) and after gel electrophoresis or oligonucleotide-based rRNA depletion (mRNA fractions) were compared. The $\Delta \Delta C_{\mathrm{T}}$ method $^{33}$ was used to minimize potential errors due to imprecise determination of the RNA concentrations of the total RNA and mRNA samples. 16S and 23S rRNA were regarded as "genes of interest" and mRNA targets as "reference genes" for internal calibration (the reverse scenario of a standard calculation of gene expression). alaS (2,631 bp) was used as internal reference for the long 
mRNA fractions and $\operatorname{rec} A(1,062 \mathrm{bp})$ for the short mRNA fractions and the mRNA after oligo-based rRNA depletion with RiboPOOL.

To calculate the mRNA:rRNA ratios as percentage, a ratio of $90 \%$ rRNA $(45 \% 23 \mathrm{~S}$ rRNA, 45\% 16S rRNA) and 1\% mRNA in the total $\mathrm{RNA}^{34}$ was assumed resulting in 1:45 ratios of mRNA:23S rRNA and mRNA:16S rRNA. Then, the calculated fold-changes for the recA:16S rRNA and alaS:23S rRNA ratios between the total RNA samples and the mRNAenriched fractions were used to calculate the final mRNA:rRNA ratios. For example, at a foldchange of 90 between alaS:23S rRNA, the mRNA:23S rRNA ratio would be $2: 1$, and similarly, for a fold-change of 90 between recA:16S rRNA, the mRNA:16S rRNA ratio would be 2:1. Taken together, the final ratio of mRNA:23S rRNA:16S rRNA would be 2:1:1 or $50 \%$ mRNA and $50 \%$ rRNA.

Analysis of mRNA enrichment by RNA sequencing - To evaluate the level of contaminating rRNA in the mRNA-enriched fractions 2 and 4, the RNA was converted into cDNA libraries using the NEBNext Ultra RNA Library Prep Kit for Illumina (New England Biolabs, USA). As a control, libraries were prepared from the corresponding total RNA. The libraries were analyzed in an HiSeq Illumina sequencer with an average sequencing depth of $\sim 8$ million single-end 50 nt-long reads. Data analysis was performed with the CLC Genomic workbench software (Qiagen, Germany) with or without duplicate removal, and both data sets were analyzed independently. To evaluate the molar ratios of RNA types in the samples, the quotient of (reads for a specific gene) / (total reads) was divided by the length of the specific gene.

MS analysis of RNA methylation - Qualitative (no internal standard, no calibration), semiquantitative (internal standard, no calibration) and absolute quantitative analyses (internal standard and calibration) of the prepared RNA fractions were performed by LC-MS/MS as previously described ${ }^{21}$. After the enzymatic hydrolysis of the RNA to nucleosides using a mixture of benzonase, snake venom phosphodiesterase and calf intestine phosphatase ${ }^{21}$, the improved gen ${ }^{13} \mathrm{C} /{ }^{15} \mathrm{~N}$ stable isotope labeled internal standard (SILIS) from S. cerevisiae tRNA was added ${ }^{32}$ for semiquantitative and absolute quantitative analysis. The resulting ribonucleoside mixture was separated using a Synergy Fusion RP column, with $2.5-\mu \mathrm{m}$ particle size, $100-\AA ̊$ pore size, 100$\mathrm{mm}$ length, and 2-mm inner diameter from Phenomenex (Torrance, CA, USA), on an Agilent 1290 Infinity II series UHPLC. Mobile phase $A$ was $5 \mathrm{mM}$ ammonium acetate adjusted to $\mathrm{pH} 5.3$ with glacial acetic acid, and mobile phase B was pure acetonitrile. Gradient elution started with $100 \%$ A for $1 \mathrm{~min}$, increased to $10 \% \mathrm{~B}$ after $4 \mathrm{~min}, 40 \%$ after $7 \mathrm{~min}$, maintained for $1 \mathrm{~min}$ and re-establishment of the starting conditions with $100 \% \mathrm{~A}$ for an additional $2.5 \mathrm{~min}$. The flow rate was 0.35 $\mathrm{mL} / \mathrm{min}$, and the column temperature was $35^{\circ} \mathrm{C}$. For MS measurements, an Agilent 6470 Triple Quadrupole mass spectrometer set to dynamic multiple reaction monitoring mode was used. The MS was operated in positive ion mode with the following parameters: skimmer voltage of $15 \mathrm{~V}$, cell accelerator voltage of $5 \mathrm{~V}, \mathrm{~N}_{2}$ gas temperature of $230{ }^{\circ} \mathrm{C}$ and $\mathrm{N}_{2}$ gas flow of 6 $\mathrm{L} / \mathrm{min}$, sheath gas $\left(\mathrm{N}_{2}\right)$ temperature of $400{ }^{\circ} \mathrm{C}$ with a flow of $12 \mathrm{~L} / \mathrm{min}$, capillary voltage of 2500 $\mathrm{V}$, nozzle voltage of $0 \mathrm{~V}$, and nebulizer at $40 \mathrm{psi}$.

\section{ACKNOWLEDGEMENT}

We are thankful to Florian Schelter, Matthias Heiß and Thomas Carell, Department of Chemistry at LMU Munich, for the MS-data presented in Figures 3 and S1.

\section{FUNDING}

This work was funded by the Deutsche Forschungsgemeinschaft (DFG, German Research Foundation): SFB1309, project number 325871075 (S.K.) and JU270/21-1, project number 464582101 (K.J.).

\section{CONFLICT OF INTEREST}

The authors declare no conflicts of interest.

\section{DATA AVAILABILITY STATEMENT}

The authors confirm that the data supporting the findings of this study are available within the article and its supplementary materials.

Raw data were generated at LAFUGA Genomics, LMU Munich. Derived data supporting the findings of this study are available from the corresponding author [K.J.] on request. 


\section{REFERENCES}

1.Kadumuri RV, Janga SC. Epitranscriptomic Code and Its Alterations in Human Disease. Trends Mol Med 2018; 24:886-903.

2. Boccaletto $P$, Machnicka MA, Purta E, Piatkowski $P$, Baginski B, Wirecki TK, et al. MODOMICS: a database of RNA modification pathways. 2017 update. Nucleic Acids Res 2018; 46:D303-07.

3. Li S, Mason CE. The pivotal regulatory landscape of RNA modifications. Annu Rev Genomics Hum Genet 2014; 15:127-50.

4. Roundtree IA, Evans ME, Pan T, He C. Dynamic RNA modifications in gene expression regulation. Cell 2017; 169:1187-200.

5. Wang $X$, He C. Dynamic RNA modifications in posttranscriptional regulation. Mol Cell 2014; 56:5-12.

6. Frye M, Harada BT, Behm M, He C. RNA modifications modulate gene expression during development. Science 2018; 361:1346-9.

7. Gilbert WV, Bell TA, Schaening C. Messenger RNA modifications: Form, distribution, and function. Science 2016; 352:1408-12.

8. Zaccara S, Ries RJ, Jaffrey SR. Reading, writing and erasing mRNA methylation. Nat Rev Mol Cell Biol 2019; 20:608-24.

9. Eyler DE, Franco MK, Batool Z, Wu MZ, Dubuke ML, Dobosz-Bartoszek M, et al. Pseudouridinylation of mRNA coding sequences alters translation. Proc Natl Acad Sci USA 2019; 116:23068-74.

10. Sergeeva OV, Bogdanov AA, Sergiev PV. What do we know about ribosomal RNA methylation in Escherichia coli? Biochimie 2015; 117:110-8.

11. Nachtergaele $\mathrm{S}, \mathrm{He} \mathrm{C}$. The emerging biology of RNA post-transcriptional modifications. RNA Biol 2017; 14:156-63.

12. Rauhut R, Klug G. mRNA degradation in bacteria. FEMS Microbiol Rev 1999; 23:353-70.

13. Deng X, Chen K, Luo GZ, Weng X, Ji Q, Zhou T, et al. Widespread occurrence of $N^{6}$-methyladenosine in bacterial mRNA. Nucleic Acids Res 2015; 43:6557-67.

14. Edelheit S, Schwartz S, Mumbach MR, Wurtzel $\mathrm{O}$, Sorek R. Transcriptome-wide mapping of 5methylcytidine RNA modifications in bacteria, archaea, and yeast reveals $\mathrm{m}^{5} \mathrm{C}$ within archaeal mRNAs. PLoS Genet 2013; 9:e1003602.

15. Motorin $Y$, Helm M. Methods for RNA Modification Mapping Using Deep Sequencing: Established and New Emerging Technologies. Genes (Basel) 2019; 10.

16. Hagelskamp F, Borland K, Ramos J, Hendrick AG, Fu D, Kellner S. Broadly applicable oligonucleotide mass spectrometry for the analysis of RNA writers and erasers in vitro. Nucleic Acids Res 2020; 48:e41.
17. Golovina AY, Sergiev PV, Golovin AV, Serebryakova MV, Demina I, Govorun VM, et al. The yfiC gene of $E$. coli encodes an adenine-N6 methyltransferase that specifically modifies A37 of tRNA $_{1}{ }^{\mathrm{Val}}$ (cmo5 $\left.{ }^{5} \mathrm{UAC}\right)$. RNA 2009; 15:1134-41.

18. Kaiser S, Byrne SR, Ammann G, Asadi Atoi P, Borland K, Brecheisen R, et al. Strategies to Avoid Artifacts in Mass Spectrometry-Based Epitranscriptome Analyses. Angew Chem Int Ed 2021; 60:23885-93.

19. Legrand C, Tuorto F, Hartmann M, Liebers R, Jacob D, Helm M, et al. Statistically robust methylation calling for whole-transcriptome bisulfite sequencing reveals distinct methylation patterns for mouse RNAs. Genome Res 2017; 27:1589-96.

20. Sergiev $P V$, Aleksashin NA, Chugunova AA, Polikanov YS, Dontsova OA. Structural and evolutionary insights into ribosomal RNA methylation. Nat Chem Biol 2018; 14:226-35.

21. Borland K, Diesend J, Ito-Kureha T, Heissmeyer $\mathrm{V}$, Hammann $\mathrm{C}$, Buck $\mathrm{AH}$, et al. Production and Application of Stable Isotope-Labeled Internal Standards for RNA Modification Analysis. Genes (Basel) 2019; 10:26.

22. Esteve-Puig $R$, Bueno-Costa $A$, Esteller $M$. Writers, readers and erasers of RNA modifications in cancer. Cancer Lett 2020; 474:127-37.

23. Squires JE, Patel HR, Nousch M, Sibbritt T, Humphreys DT, Parker BJ, et al. Widespread occurrence of 5-methylcytosine in human coding and non-coding RNA. Nucleic Acids Res 2012; 40:502333.

24. Li X, Zhu P, Ma S, Song J, Bai J, Sun F, et al. Chemical pulldown reveals dynamic pseudouridylation of the mammalian transcriptome. Nat Chem Biol 2015; 11:592-7.

25. Zhang LS, Liu C, Ma H, Dai Q, Sun HL, Luo G, et al. Transcriptome-wide Mapping of Internal $N^{7}$ Methylguanosine Methylome in Mammalian mRNA. Mol Cell 2019; 74:1304-16.e8.

26. Antonicka H, Choquet $\mathrm{K}$, Lin ZY, Gingras AC, Kleinman CL, Shoubridge EA. A pseudouridine synthase module is essential for mitochondrial protein synthesis and cell viability. EMBO Rep 2017; 18:28-38.

27. Enroth C, Poulsen LD, Iversen S, Kirpekar F, Albrechtsen A, Vinther J. Detection of internal $N^{7}$ methylguanosine $\mathrm{m}^{7} \mathrm{G}$ RNA modifications by mutational profiling sequencing. Nucleic Acids Res 2019; 47:e126.

28. Furuichi $Y$. Discovery of $m^{7} G$-cap in eukaryotic mRNAs. Proc Jpn Acad Ser B Phys Biol Sci 2015; 91:394-409.

29. Grenier F, Matteau D, Baby V, Rodrigue S. Complete Genome Sequence of Escherichia coli BW25113. Genome Announc 2014; 2. 
30. Sambrook J, Russell DW. Purification of nucleic acids by extraction with phenol:chloroform. Cold Spring Harb Protoc 2006; 2006.

31. Heiss M, Reichle VF, Kellner S. Observing the fate of tRNA and its modifications by nucleic acid isotope labeling mass spectrometry: NAIL-MS. RNA Biol 2017; 14:1260-8.

32. Heiss $\mathrm{M}$, Borland $\mathrm{K}$, Yoluç $\mathrm{Y}$, Kellner $\mathrm{S}$. Quantification of Modified Nucleosides in the Context of NAIL-MS. Methods Mol Biol 2021; 2298:279-306.
33. Schmittgen TD, Livak KJ. Analyzing real-time PCR data by the comparative $C_{\mathrm{T}}$ method. Nat Protoc 2008; 3:1101-8.

34. Westermann AJ, Gorski SA, Vogel J. Dual RNAseq of pathogen and host. Nat Rev Microbiol 2012; 10:618-30.

\section{SUPPLMENTAL MATERIAL}

Figure S1. Quality controls for the separation of total RNA from E. coli into fractions of tRNA and rRNA+mRNA.

Figure S2. Quality control for the enrichment of mRNA after tRNA removal and rRNA depletion.

Figure S3. RT-qPCR quality controls for enrichment of mRNA after isolation from denaturing agarose gels.

Figure S4. Modification profiles of mRNA, tRNA, and rRNA in E. coli.

Figure S5. Quantitative analysis of $\mathrm{m}^{2} \mathrm{~A}$ in RNA of $E$. coli after denaturing agarose gel electrophoresis.

Figure S6. Dynamics of the rRNA+mRNA modifications during growth of E. coli.

Figure S7. Quantitative analysis of modifications in RNA of microaerobically grown E. coli after separation with denaturing gel electrophoresis. 